CLINICAL STUDY

\title{
Influence of physical mobility and season on 25-hydroxyvitamin D-parathyroid hormone interaction and bone remodelling in the elderly
}

Robert Theiler, Hannes Balthasar Stähelin ${ }^{1}$, Marius Kränzlin ${ }^{2}$, Gyula Somorjai, Lyn Singer-Lindpaintner ${ }^{1}$, Martin Conzelmann ${ }^{1}$, Piet Geusens ${ }^{3}$ and Heike Annette Bischoff ${ }^{1}$

Departments of Rheumatology, ${ }^{1}$ Geriatrics and ${ }^{2}$ Endocrine Practice, University of Basel, Switzerland and ${ }^{3}$ Dr L Willems-Instituut, Diepenbeek, Belgium

(Correspondence should be addressed to H A Bischoff, Department of Orthopedics, Felix Platter Spital, Burgfelderstrasse 101, 4012 Basel, Switzerland; Email: hbischof@hsph.harvard.edu or R Theiler, Department of Rheumatology, Kantonsspital Aarau, 5001 Aarau, Switzerland)

\begin{abstract}
Objective: To investigate influences of physical mobility and season on 25-hydroxyvitamin D-intact parathyroid hormone (iPTH) interaction in the elderly.

Design: We examined 188 frail institutionalized elderly at the expected nadir of their serum vitamin D concentrations (winter). This group was compared with 309 healthy ambulatory elderly at the expected time of maximum vitamin D repletion (summer), to accentuate the influences of season and physical activity.

Methods: Serum concentrations of 25-hydroxyvitamin D, 1,25-dihydroxyvitamin D, iPTH and urinary deoxypyridinoline (DPD) were measured.

Results: Vitamin D metabolites were significantly lower in the institutionalized elderly $(P<0.0001)$, with an $82.5 \%$ prevalence of vitamin D deficiency (25-hydroxyvitamin D $<12 \mathrm{ng} / \mathrm{ml}$ ) in institutionalized elderly in wintertime and $15.5 \%$ in ambulatory elderly in summertime. Overall, median iPTH did not differ between groups. However, median iPTH secretion in the presence of low vitamin D serum concentrations $(5-30 \mathrm{ng} / \mathrm{ml})$ was greater in ambulatory elderly. This could be explained by lower mobility status being correlated with greater serum calcium concentrations $(r=0.24, P=0.02$ in women; $r=0.35, P=0.001$ in men) and greater urinary excretion of DPD $(r=0.41, P=0.0001$ in women; $r=0.42, P=0.0002$ in men), independent of 25 -hydroxyvitamin $\mathrm{D}, 1,25$-dihydroxyvitamin $\mathrm{D}$ and iPTH.

Conclusions: These data support the hypothesis that immobility, even in the presence of vitamin D deficiency, acts as an overriding influence on bone metabolism by promoting bone resorption (measured as urinary DPD) and increasing serum calcium independent of iPTH. Therefore mobility status may substantially affect 25 -hydroxyvitamin D threshold values and the degree to which patients benefit from vitamin supplementation.
\end{abstract}

European Journal of Endocrinology 143 673-679

\section{Introduction}

Vitamin D is needed to maintain calcium absorption and skeletal integrity $(1-4)$. It has been suggested that the evolution of osteoporosis in the elderly is promoted by hypovitaminosis D and secondary hyperparathyroidism $\left(2{ }^{\circ} \mathrm{HPT}\right)$. The consequence of an increase in parathyroid hormone (PTH) would be an increase in bone remodeling activity, which is reflected in documented abnormalities of bone biomarkers and fragility fractures (5). The threshold concentrations of 25hydroxyvitamin $\mathrm{D}$ below which these abnormalities occur are being defined by current research $(6,7)$. Even small increases in PTH concentrations may have potentially harmful bone effects. Recent studies have shown that threshold levels of 25-hydroxyvitamin D needed by elderly patients to restore PTH concentrations to the low values seen in young adults might be greater than the lower physiological threshold proposed by Lips $(12 \mathrm{ng} / \mathrm{ml}, 30 \mathrm{nmol} / \mathrm{l})(7)$.

In a recent publication McKenna \& Freaney (6) defined vitamin $\mathrm{D}$ thresholds below which occurrence of $2^{\circ} \mathrm{HPT}$ and abnormalities in bone metabolism are expected. They defined four levels of 25-hydroxyvitamin D including desirable 25-hydroxyvitamin D status (>100 nmol/l, >40 ng/ml), hypovitaminosis D $(<100$ 
$\mathrm{nmol} / \mathrm{l},<40 \mathrm{ng} / \mathrm{ml})$, vitamin D insufficiency $(<50 \mathrm{nmol} /$ $\mathrm{l},<20 \mathrm{ng} / \mathrm{ml})$ and vitamin D deficiency $(<25 \mathrm{mmol} / \mathrm{l}$, $<10 \mathrm{ng} / \mathrm{ml}$ ). Thresholds differ between studies, which might be influenced by age and by life-style factors such as sedentary status and physical mobility. For example, irrespective of the country of residence, communitydwelling elderly have greater 25-hydroxyvitamin D and lower PTH serum concentrations than housebound or institutionalized elderly. European studies tend to document lower 25-hydroxyvitamin D concentrations and greater PTH than their counterparts in the USA, Australia or Japan $(3,4)$, which is probably due to a lack of vitamin-D-fortified food in Europe. Moreover, young people seem to have a different threshold for increased PTH than do elderly people (8). Impaired function of $1 \alpha$ hydroxylase in the ageing kidney has been proposed as a possible mechanism (8).

The aim of the present study was to investigate a particular lifestyle factor, physical mobility, that might influence the threshold relationship between 25-hydroxyvitamin D and intact (iPTH) in the elderly. Therefore two groups of elderly individuals, selected to differ markedly in their levels of weight-bearing activity and risk factors for vitamin D deficiency, such as season and sedentary status, were compared for their serum vitamin D concentrations, their corresponding iPTH serum concentrations, and biochemical markers of bone remodelling.

\section{Methods}

\section{Participants}

A total of 495 elderly people were enrolled in a crosssectional study between January 1995 and August 1995. They were categorized according to sex and living situation: 309 ambulatory elderly people (107 women: mean age 74 years, range: $62-86$ years; 202 men: mean age 76 years, range: $66-95$ years) and 188 institutionalized geriatric residents (103 women: mean age 83 years, range: 59-99 years; 85 men: mean age 78 years, range: 56-94 years). The demographic characteristics of the participants are shown in Table 1.

All institutionalized elderly people were recruited from the long-stay geriatric unit of the University Hospital, Basel. Mean duration of stay was 32 weeks (women 26 weeks; men 39 weeks). Measurements took place between January and March (wintertime) in the institutionalized group, and between April and August (summertime) in the ambulatory group, in an attempt to accentuate as much as possible the differences in serum vitamin D hormone concentrations (25-hydroxyvitamin D, 1,25-dihydroxyvitamin D) in the elderly population.

All ambulatory elderly people lived independently and were able to walk alone, a minority using a walking stick for ambulation.
Table 1 Baseline characteristics of the 188 institutionalized and 309 ambulatory elderly. Values are median (interquartile range) or number.

\begin{tabular}{lll}
\hline & \multicolumn{1}{c}{ Women } & \multicolumn{1}{c}{ Men } \\
\hline Institutionalized elderly & $(n=103)$ & $(n=85)$ \\
Age (years) & $84(77-89)$ & $79(72-86)$ \\
BMl (kg/m $\left.{ }^{2}\right)$ & $24.3(21.5-26.6)$ & $24.8(22.1-27.6)$ \\
Mobility group $\dagger$ & & \\
$\quad 0=$ fully mobile & 0 & 0 \\
$1=$ mobile & 20 & 22 \\
$2=$ walking aid & 35 & 30 \\
$3=$ wheelchair & 26 & 20 \\
$4=$ bedridden $>50 \%$ & 22 & 13 \\
Ambulatory elderly & $(n=107)$ & $(n=202)$ \\
Age (years) & $73(70-77.8)$ & $74.5(71-81)$ \\
BMl (kg/m $)$ & $24.5(22.6-27.1)$ & $24.9(23.2-27.0)$ \\
Mobility group $\dagger$ & & \\
$\quad 0=$ fully mobile & 107 & 202 \\
\hline
\end{tabular}

†For definition of mobility groups, see Methods section.

The ambulatory group were part of the Basel longitudinal Inter-Disciplinary Study on Ageing (IDA) project, which has been in progress since 1993 (9). The project is a follow-up to a medical longitudinal study, the Basle Prospective Study, that collected biomedical data from a large sample of 6400 healthy people in 1960, 1965 and 1971 (10). For the continuing IDA study, the participants were required to be 65 years or older. The ambulatory group was selected by random sampling from the large sample that comprised 2959 men and 809 women in 1993.

Each participant was assigned to one of five physical activity groups based on three sources of information: the participant's own assessments of their physical activity were elicited, together with the observations of nursing staff in the institutionalized group and one physician investigator. If the participant was unable to provide a reliable assessment, the family was consulted. The observations rarely disagreed. Physical activity group 0 comprised those who walked outside more than twice a week. All ambulatory elderly were in this group, but no institutionalized elderly person was. Physical activity groups 1-4 included only the institutionalized elderly. Those assigned to activity group 1 were able to walk independently, a minority using a walking stick for ambulation; they were able to walk outside once or twice a week. Participants assigned to activity group 2 were less physically active, the majority using a walking stick or a walking frame; they left the facility less than once weekly, but required no wheelchair. Activity group 3 included persons most of whom required wheelchairs, but who spent more than 50\% of their day sitting, rather than lying in bed. Group 4 comprised bedridden elderly, who spent more than half of each day in bed.

The study procedure was approved by the hospital ethics commitee. Oral informed consent was obtained from all participants or from their legal guardians. 
Participants had not received any treatment for a bone disorder with calcium, vitamin D, hormone replacement therapy, calcitonin, fluoride, or bisphosphonates during the previous 6 months. Exclusion criteria were a history of recent hip fracture (within 3 years), history of hypercalcemia, urolithiasis, sarcoidosis and primary HPT. Individuals with creatinine values greater than the normal range $(<120 \mu \mathrm{mol} / \mathrm{l})$ were excluded.

Current calcium intake was measured in the ambulatory individuals by means of a frequency and amount questionnaire, which contained information about the consumption of 15 food items: milk, yoghurt, hard cheese, soft cheese, chocolate, meat or fish, eggs, potatoes, pasta, vegetables, bread, fruits, water or mineral water, alcoholic beverages, or fruit juice. For the institutionalized elderly, a dietitian evaluated the mean calcium content of food consumed from each meal and drink during the week of baseline measurements.

All measurements were performed locally at the Geriatric University Hospital of Basel (latitude 47,33 North; longitude $7,35^{\circ}$ East).

\section{Samples and assays}

Fasting early morning venous blood was collected from resting individuals for measurement of serum concentrations of calcium, phosphate, albumin and total alkaline phosphatase. These substances were measured using automated serum chemical analysis. Blood calcium concentration was corrected for albumin with the following formula: corrected calcium $=$ measured calcium $(\mathrm{mmol} / \mathrm{l})-0.012 \times(\operatorname{albumin}(\mathrm{g} / \mathrm{l})-39.5)(11)$.

iPTH serum concentration was measured by an immunoradiometric assay (Intact PTH; Nichols) in EDTA plasma. The upper normal limit, indicating $2^{\circ} \mathrm{HPT}$, was set at $>54 \mathrm{pg} / \mathrm{ml}$ (7). On two separate determinations, intra-assay variation was 1.8 and $3.4 \%$ and interassay variation 5.6 and $6.1 \%$.

For 25-hydroxyvitamin D and 1,25-dihydroxyvitamin D serum concentration measurements, radioimmunoassays (Nichols, San Juan Capistrano, CA, USA) were used (vitamin D deficiency was defined as 25-hydroxyvitamin D serum concentrations less than $12 \mathrm{ng} / \mathrm{ml}$ or $30 \mathrm{nmol} / \mathrm{l}(12))$. Intra-assay variation was 5.1 and $9.2 \%$ and interassay variation 7.9 and $12.6 \%$ for the 25-hydroxyvitamin D assay; respective variations were 4.8 and $10.6 \%$, and 10.8 and $16.8 \%$, for the $1,25-$ dihadroxyvitamin D assay.

Urinary deoxypyridinoline (DPD) was measured by reverse-phase ion-paired HPLC after complete acid hydrolysis of the urine and prefractionation of the hydrolysate on a CF-1 cellulose column (NTx, Osteomark, Seattle, WA, USA). The intra- and interassay variations were $4.6 \%$ and $10.2 \%$. DPD determinations

Table 2 Median (interquartile range) concentrations of parameters measured in serum and urine for institutionalized and ambulatory elderly women and men.

\begin{tabular}{|c|c|c|c|c|c|c|}
\hline \multirow[b]{2}{*}{$\begin{array}{l}\text { Parameter } \\
\text { (normal range) }\end{array}$} & \multicolumn{3}{|c|}{ Women } & \multicolumn{3}{|c|}{ Men } \\
\hline & $\begin{array}{l}\text { Institutionalized } \\
\quad(n=103)\end{array}$ & $\begin{array}{l}\text { Ambulatory } \\
(n=107)\end{array}$ & $P^{\star}$ & $\begin{array}{l}\text { Institutionalized } \\
\qquad(n=85)\end{array}$ & $\begin{array}{l}\text { Ambulatory } \\
(n=202)\end{array}$ & $P^{\star}$ \\
\hline Age (years) & $\begin{array}{l}84 \\
(77-89)\end{array}$ & $\begin{array}{l}73 \\
(70-77.8)\end{array}$ & $<0.0001$ & $\begin{array}{l}79 \\
(72-86)\end{array}$ & $\begin{array}{l}74.5 \\
(71-81)\end{array}$ & 0.02 \\
\hline $\begin{array}{l}\text { 25(OH)D (ng/ml)† } \\
(\geq 12 \mathrm{ng} / \mathrm{ml})\end{array}$ & $\begin{array}{l}5 \\
(2-9.3)\end{array}$ & $\begin{array}{l}22 \\
(15.3-35.5)\end{array}$ & $<0.0001$ & $\begin{array}{c}4 \\
(2-9)\end{array}$ & $\begin{array}{l}36 \\
(15-54)\end{array}$ & $<0.0001$ \\
\hline $1,25(\mathrm{OH})_{2} \mathrm{D}(\mathrm{pg} / \mathrm{ml}) \ddagger$ & $\begin{array}{l}26 \\
(20-34)\end{array}$ & $\begin{array}{l}39 \\
(31.3-48.8)\end{array}$ & $<0.0001$ & $\begin{array}{l}26 \\
(18-36.8)\end{array}$ & $\begin{array}{l}37.5 \\
(32-45)\end{array}$ & $<0.0001$ \\
\hline $\begin{array}{l}\text { ¡PTH }(\mathrm{pg} / \mathrm{ml}) \dagger \\
(<55 \mathrm{pg} / \mathrm{ml})\end{array}$ & $\begin{array}{l}40.5 \\
(27-56.5)\end{array}$ & $\begin{array}{l}42 \\
(34-51)\end{array}$ & 0.5 & $\begin{array}{l}34 \\
(21.3-48)\end{array}$ & $\begin{array}{l}37.5 \\
(29-49)\end{array}$ & 0.06 \\
\hline $\begin{array}{l}\text { Calcium }(\mathrm{mmol} / \mathrm{l}) \Phi \\
(2.2-2.64 \mathrm{mmol} / \mathrm{l})\end{array}$ & $\begin{array}{l}2.3 \\
(2.24-2.37)\end{array}$ & $\begin{array}{l}2.32 \\
(2.23-2.39)\end{array}$ & 0.7 & $\begin{array}{l}2.31 \\
(2.24-2.38)\end{array}$ & $\begin{array}{l}2.27 \\
(2.2-2.36)\end{array}$ & 0.03 \\
\hline $\begin{array}{l}\text { Albumin }(\mathrm{g} / \mathrm{l}) \\
(35-50 \mathrm{~g} / \mathrm{l})\end{array}$ & $\begin{array}{l}39 \\
(36-42)\end{array}$ & $\begin{array}{l}42.5 \\
(39-45)\end{array}$ & $<0.0001$ & $\begin{array}{l}39 \\
(36-42)\end{array}$ & $\begin{array}{l}42.5 \\
(39-45)\end{array}$ & $<0.0001$ \\
\hline $\begin{array}{l}\text { Phosphate }(\mathrm{mmol} / \mathrm{l}) \\
(0.87-1.45 \mathrm{mmol} / \mathrm{l})\end{array}$ & $\begin{array}{l}1.1 \\
(1.0-1.2)\end{array}$ & $\begin{array}{l}1.2 \\
(1.1-1.3)\end{array}$ & $<0.001$ & $\begin{array}{l}1.1 \\
(1.0-1.2)\end{array}$ & $\begin{array}{l}1.2 \\
(1.1-1.3)\end{array}$ & $<0.001$ \\
\hline $\begin{array}{l}\text { Creatinine }(\mu \mathrm{mol} / \mathrm{l}) \\
(45-117 \mu \mathrm{mol} / \mathrm{II})\end{array}$ & $\begin{array}{l}72 \\
(62-85)\end{array}$ & $\begin{array}{l}69 \\
(61-76)\end{array}$ & 0.06 & $\begin{array}{l}85 \\
(73-95)\end{array}$ & $\begin{array}{l}84 \\
(75.8-93)\end{array}$ & 0.92 \\
\hline $\begin{array}{l}\text { Alkaline phosphatase }(\mathrm{U} / \mathrm{l}) \dagger \\
(31-108 \mathrm{U} / \mathrm{l})\end{array}$ & $\begin{array}{l}85.5 \\
(72.8-102.5)\end{array}$ & $\begin{array}{l}75 \\
(65-89.8)\end{array}$ & 0.001 & $\begin{array}{l}80 \\
(69-95)\end{array}$ & $\begin{array}{l}73 \\
(62.5-90)\end{array}$ & 0.001 \\
\hline $\begin{array}{l}\text { DPD }(\mathrm{nmol} / \mathrm{mmol}) \\
(<16 \mathrm{nmol} / \mathrm{mmol}))\end{array}$ & $\begin{array}{l}25.9 \\
(16.8-39.1)\end{array}$ & $\begin{array}{l}14.6 \\
(10.9-19.2)\end{array}$ & $<0.0001$ & $\begin{array}{l}19.7 \\
(13.1-30.2)\end{array}$ & $\begin{array}{l}12.7 \\
(9.4-18.2)\end{array}$ & $<0.0001$ \\
\hline $\begin{array}{l}\text { Calcium/creatinine§ } \\
(<0.3)\end{array}$ & $\begin{array}{l}0.46 \\
(0.27-0.64)\end{array}$ & $\begin{array}{l}0.22 \\
(0.13-0.43)\end{array}$ & $<0.0001$ & $\begin{array}{l}0.33 \\
(0.19-0.65)\end{array}$ & $\begin{array}{l}0.18 \\
(0.12-0.28)\end{array}$ & 0.4 \\
\hline
\end{tabular}

25(OH)D, 25-hydroxyvitamin $\mathrm{D} ; 1,25(\mathrm{OH})_{2} \mathrm{D}, 1,25$-dihydroxyvitamin $\mathrm{D}$.

$n$, Number of patients. *Wilcoxon test. †To convert values for $25(\mathrm{OH}) \mathrm{D}$ to $\mathrm{nmol} / \mathrm{l}$, multiply by 2.5 ; to convert values for iPTH to pmol/l, multiply by 0.11 ; to convert values for alkaline phosphatase to $\mu$ kat/l, multiphy by 0.0167 . $\ddagger$ Normal values for $1,25(\mathrm{OH})_{2} \mathrm{D}$ are uncertain. $\uparrow$ Serum calcium after correction for serum albumin. §Urinary calcium/creatinine ratio. 
were performed on second fasting morning urine samples. Blood for vitamin D metabolites was collected in a light-protected fashion.

\section{Statistical analysis}

Data were analysed by SPSS computer program. Results with $P$ values $<0.05$ were considered statistically significant. As the data are slightly skewed, all data collected for women and men were compared using Wilcoxon's test for unpaired data. The coefficients of correlation were calculated by the Spearman rank sum method. In each group, mean values for measured parameters were calculated. ANCOVA was used to explain $\ln (25$-hydroxyvitamin D) by age, sex, iPTH, serum calcium and life-style plus seasonality. $\ln (25-$ Hydroxyvitamin D) was chosen in order to obtain normal residuals. Factors that reached significance are cited in decreasing order of mean sum of squares. ANCOVA was used to explain DPD excretion in all participants and separately in ambulatory elderly with only one mobility group.

\section{Results}

A total of 495 participants were enrolled in the study. Their characteristics are shown in Table 1. Median values obtained for measured parameters in women and men of both categories are summarized in Table 2 . Significant differences were found in concentrations of serum vitamin D metabolites (calcidiol, calcitriol), albumin and urinary DPD excretion. Calcium intake was low in both groups (institutionalized: 600-700 $\mathrm{mg}$ /day; ambulatory: 500-700 mg/day).

Vitamin D status in institutionalized elderly at the expected nadir (wintertime) compared with ambulatory elderly at the expected maximum (summertime) are depicted in Fig. 1 (6). Severe vitamin D deficiency (25-hydroxyvitamin D $<5 \mathrm{ng} / \mathrm{ml} ;<15 \mathrm{nmol} / \mathrm{l}$ ) was found in 107 institutionalized elderly $(56.9 \%)$ in wintertime and 13 ambulatory elderly (4.2\%) in summertime. The prevalence of vitamin $\mathrm{D}$ deficiency (25-hydroxyvitamin D $<12 \mathrm{ng} / \mathrm{ml} ;<30 \mathrm{nmol} / \mathrm{l}$ ) was $82.5 \%$ (155 individuals) in institutionalized elderly, compared with $15.5 \%$ (48 individuals) in ambulatory elderly. Vitamin D insufficiency (25-hydroxyvitamin D $12-19 \mathrm{ng} / \mathrm{ml}$; $30-49 \mathrm{nmol} / \mathrm{l}$ ) was present in $10.1 \%$ (19 individuals) of institutionalized and 19.7\% (61 individuals) of ambulatory elderly. Twelve institutionalized elderly $(6.4 \%)$ and 95 ambulatory elderly $(30.7 \%)$ had hypovitaminosis D (25-hydroxyvitamin D $20-40 \mathrm{ng} / \mathrm{ml} ; 50-100 \mathrm{nmol} / \mathrm{l})$. Desirable vitamin D status $(>40 \mathrm{ng} / \mathrm{ml} ;>100 \mathrm{nmol} / \mathrm{l}$ ) was attained in two institutionalized elderly (1.1\%) and 105 ambulatory elderly (34.1\%).

In an ANCOVA, including all participants, life-style plus season, iPTH and age explained $55 \%\left(r^{2}=0.55\right)$ of total variation of $\ln (25$-hydroxyvitamin $D)$.

\section{Vitamin D metabolites and prevalence of $\mathbf{2}^{\circ} \mathrm{HPT}$}

Median 25-hydroxyvitamin D and 1,25-dihydroxyvitamin D serum concentrations of institutionalized elderly measured during January to March differed significantly from the mean summer values in ambulatory elderly (Table 2).

Median serum iPTH concentrations were slightly greater in women than in men in both groups (institutionalized: $40.5 \mathrm{pg} / \mathrm{ml}$ in women and $34.0 \mathrm{pg} / \mathrm{ml}$ in men, compared with ambulatory: $42.0 \mathrm{pg} / \mathrm{ml}$ in women and $37.5 \mathrm{pg} / \mathrm{ml}$ in men), but did not differ significantly between institutionalized and ambulatory elderly. Using an upper normal limit for iPTH of $54 \mathrm{pg} / \mathrm{ml}, 2^{\circ} \mathrm{HPT}$ occurred in $22 \%$ of female and $15 \%$ of male participants in the ambulatory group, and in $25 \%$ of female and $21 \%$ of male participants in the institutionalized group.

In both groups, 25-hydroxyvitamin $\mathrm{D}$ and iPTH serum concentrations were negatively correlated (institutionalized: $r=-0.29, P=0.003$ in women and $r=-0.33, \quad P=0.003$ in men; ambulatory: $r=-0.24, P=0.01$ in women and $r=-0.26$, $P=0.0002$ in men). Intact PTH serum concentrations increased with age in the institutionalized elderly (women: $r=0.29, \quad P=0.004$; men: $r=0.23$,

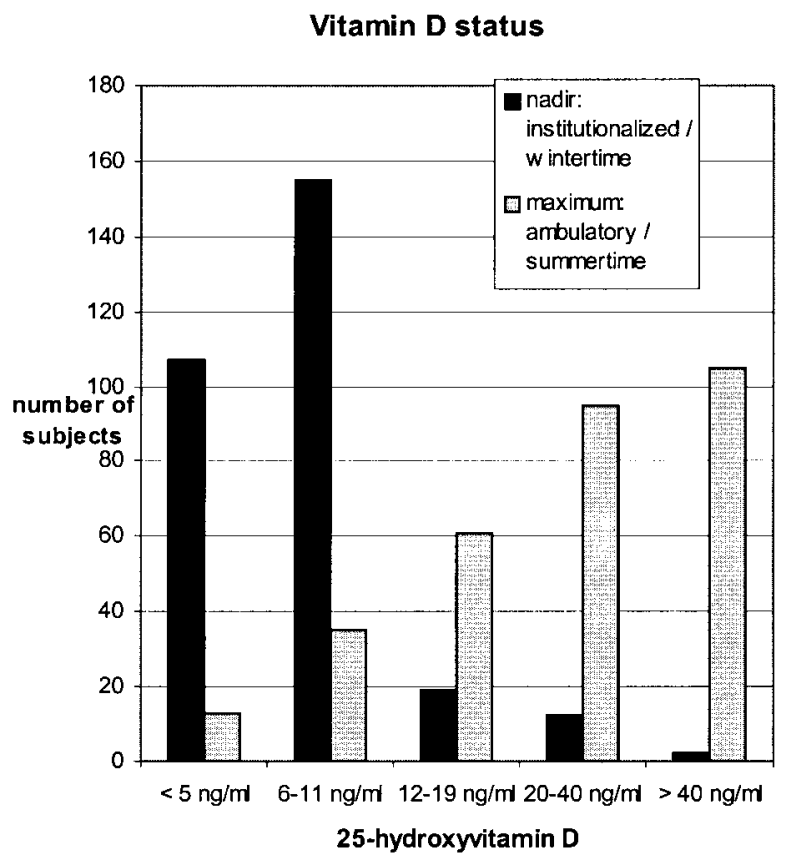

Figure 125 -Hydroxyvitamin D status in 188 institutionalized elderly in wintertime and 309 ambulatory elderly in summertime: severe vitamin $D$ deficiency (25-hydroxyvitamin $D<5 \mathrm{ng} / \mathrm{ml}$; $<15 \mathrm{nmol} / \mathrm{l})$, vitamin D deficiency (25-hydroxyvitamin $\mathrm{D}<12 \mathrm{ng} / \mathrm{ml}$; $<30 \mathrm{nmol} / \mathrm{l})$, vitamin D insufficiency (25-hydroxyvitamin D 12-19 ng/ $\mathrm{ml}$; 30-49 nmol/l), hypovitaminosis D (25-hydroxyvitamin D 20$40 \mathrm{ng} / \mathrm{ml} ; 50-100 \mathrm{nmol} / \mathrm{l})$ and desirable vitamin D status (>40 ng/ml; $>100 \mathrm{nmol} / \mathrm{l})$. Percent values are given in the results section (6). 

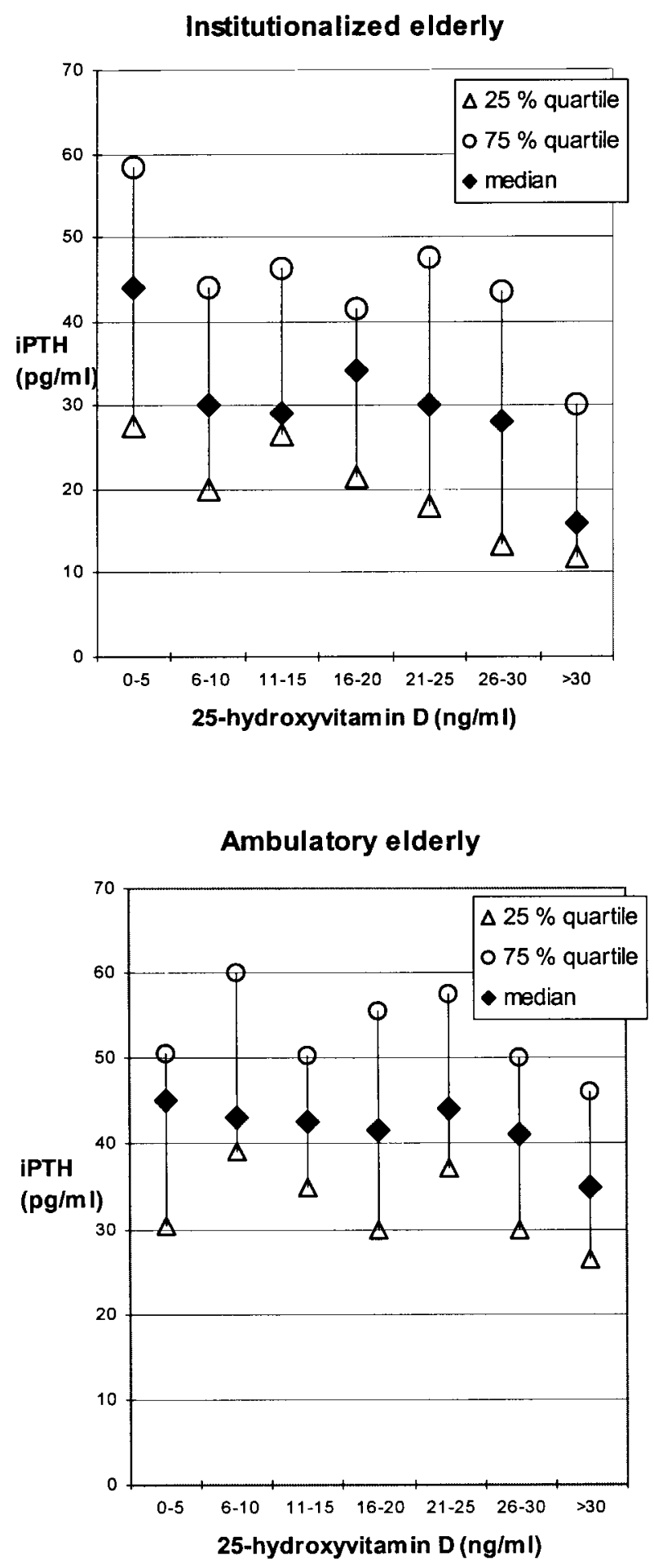

Figure 2 Median serum concentrations of IPTH in institutionalized elderly in wintertime and ambulatory elderly in summertime per $5 \mathrm{ng} / \mathrm{ml}$ increments of 25-hydroxyvitamin D.
$P=0.03$ ) and in ambulatory elderly (women: $r=0.21$, $P=0.03$; men: $r=0.12, P=0.09$ ). For both groups, no significant correlation was found between 1,25dihydroxyvitamin D and iPTH.

\section{Relationship between 25-hydroxyvitamin D and iPTH serum concentrations}

Median iPTH serum concentrations for $5 \mathrm{ng} / \mathrm{ml}$ increments of 25-hydroxyvitamin D serum concentrations for institutionalized and ambulatory elderly are shown in Fig. 2. In institutionalized elderly, median serum iPTH concentrations were about $30 \mathrm{pg} / \mathrm{ml}$ for 25hydroxyvitamin D concentrations ranging from 6 to $30 \mathrm{ng} / \mathrm{ml}$. In the ambulatory group, median iPTH serum concentrations were between 40 and $50 \mathrm{pg} / \mathrm{ml}$ iPTH at serum concentrations of 25-hydroxyvitamin D ranging from 1 to $30 \mathrm{ng} / \mathrm{ml}$. Institutionalized elderly attained iPTH serum concentrations greater than $40 \mathrm{pg} / \mathrm{ml}$ only as serum concentrations of 25-hydroxyvitamin $\mathrm{D}$ decreased to less than $6 \mathrm{ng} / \mathrm{ml}$. In both groups, lowest iPTH serum concentrations were found in 25-hydroxyvitamin D concentrations $>30 \mathrm{ng} / \mathrm{ml}$; however, there was a greater median iPTH serum concentration in the ambulatory group.

\section{Vitamin D, iPTH and bone resorption}

Urinary DPD excretion was measured as a marker for bone resorption. Both sexes showed greater values for urinary DPD excretion rate in the institutionalized group $(P=0.0001)$. In the institutionalized elderly, no correlation was found between serum iPTH or 25hydroxyvitamin D and urinary DPD or mobility score.

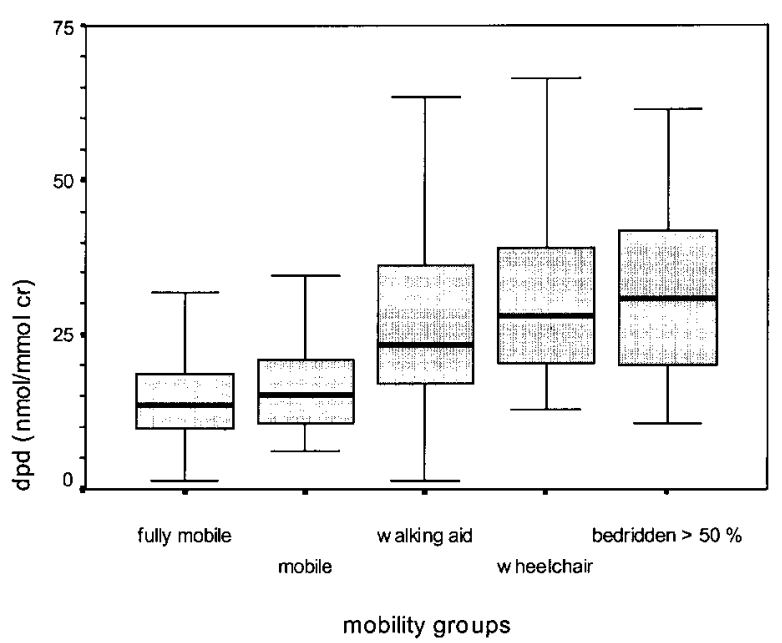

Figure 3 Box plot for urinary DPD concentrations in five mobility groups: ambulatory elderly (fully mobile, $n=303$ ) and institutionalized elderly (mobile, $n=55$; walking aid, $n=41$; wheelchair, $n=42$; bedridden, $n=29$ ). There was an increased excretion of DPD in more immobile groups. 
However, a positive correlation was documented between mobility score and both serum calcium (women: $r=0.24, P=0.02$; men: $r=0.35, P=0.001)$ and urinary DPD (women: $r=0.41, P=0.0001$; men: $r=0.42, \quad P=0.0002)$. Urinary calcium/creatinine ratio was greater in institutionalized elderly (women: $P=0.0001$, men: $P=0.0001)$. Box plots for urinary DPD were compared for five mobility groups and are shown in Fig. 3. In an ANCOVA, including institutionalized and ambulatory elderly, only the level of physical mobility reached significance and explained $20.3 \%$ of total variation of DPD excretion. Other factors tested in this model were vitamin D metabolites, iPTH, albumin, serum calcium, alkaline phosphatase, sex, body mass index, age and sedentary status. If ambulatory elderly were analysed separately, none of these factors reached significance, and a combination of all factors explained $16.7 \%$ of total variation of DPD excretion.

\section{Discussion}

These results indicate that, in Switzerland, vitamin D deficiency is common in institutionalized elderly during wintertime $(83 \%)$, but much less common in ambulatory elderly during summertime (16\%). However, only 34\% of ambulatory elderly in summertime showed desirable 25hydroxyvitamin D serum concentrations (>40 ng/ml; $>100 \mathrm{nmol} / \mathrm{l}$ ) as proposed by McKenna \& Freaney (6). Low 25-hydroxyvitamin D serum concentrations in the institutionalized population and high 25-hydroxyvitamin D serum concentrations in ambulatory elderly were, as expected, predicted by seasonality and residential status $(4,13)$. As only $34 \%$ of ambulatory elderly in summertime had desirable 25-hydroxyvitamin D serum concentrations $(>40 \mathrm{ng} / \mathrm{ml})$, and $16 \%$ were vitamin-Ddeficient $(<12 \mathrm{ng} / \mathrm{ml})$, our results indicate that, even for our lower-risk group of independently living elderly, vitamin D supplementation should be recommended in order to restore iPTH concentrations in the elderly to those found in young adults (14).

Contrary to expectations and despite major differences in vitamin D status and age, equal median serum concentrations of iPTH were seen in ambulatory elderly in summertime and institutionalized elderly in wintertime. In fact, we would have expected increased median iPTH in institutionalized elderly, because of both lower 25-hydroxyvitamin D concentrations and greater age $(1,2,6)$. Another unexpected finding was that neither 25-hydroxyvitamin D nor iPTH serum concentrations correlated with bone resorption as measured by urinary excretion of DPD. However, more immobile individuals had greater serum calcium concentrations and greater excretion rates for urinary DPD. Therefore the increase in bone resorption in the group of institutionalized elderly could be related to immobility, rather than to $2^{\circ}$ HPT. This might be explained by an immobilityinduced increase in serum calcium as a result of bone resorption and resulting suppression of serum iPTH concentrations. The uncoupling of the $25(\mathrm{OH}) \mathrm{D}-\mathrm{PTH}$ axis is reflected in a rather low incidence $(25 \%$ of female and $21 \%$ of male institutionalized elderly) of $2^{\circ} \mathrm{HPT}$ (iPTH $>55 \mathrm{pg} / \mathrm{ml}$ ) in a population with a high incidence of vitamin D deficiency (83\%). We conclude that, in institutionalized elderly, immobility has a strong impact on bone metabolism. This might counteract the development of $2^{\circ} \mathrm{HPT}$ through increased serum calcium (15), which is consistent with our finding of a positive correlation between mobility score and both serum calcium and urinary DPD. These results are similar to those seen in younger persons during shortterm bed rest (16) and in astronauts during space flight (17), with primary bone loss as a result of immobility or weightlessness-induced negative calcium balance. In addition Sorva and colleagues (18) reported that bedridden elderly patients do not benefit from vitamin D supplementation with increased bone resorption, which is in contrast to the findings of studies performed in more mobile elderly populations (5).

However, despite this strong influence of immobility on 25-hydroxyvitamin D and iPTH interaction, correlation studies between 25-hydroxyvitamin D and iPTH remained significant and were more pronounced in institutionalized elderly than in ambulatory elderly. Therefore both vitamin D deficiency, as suggested by Chapuy and colleagues (14), and immobility, as suggested by the present data, influence serum PTH concentrations. Nevertheless bone resorption seems to be driven by immobility, and if present, even in vitamin-D-deficient elderly.

The suggested impact of mobility status on serum iPTH concentrations might influence threshold values of 25-hydroxyvitamin $\mathrm{D}$, which have been found to vary (6). On the basis of a comparison of reports in the elderly of baseline vitamin D and PTH status and the response to vitamin D therapy, McKenna \& Freaney (6) proposed a threshold concentration greater than $40 \mathrm{ng} / \mathrm{ml}$ (>100 nmol/l), whereas Lips and colleagues (12) proposed the much lower value of $30 \mathrm{nmol} / \mathrm{l}(12 \mathrm{ng} / \mathrm{ml})$. Chapuy and colleagues (7) demonstrated, in the Decalyos study, a threshold concentration of $105 \mathrm{nmol} / \mathrm{l}$ at which prevention of hip fracture by supplementation of vitamin D and calcium occurred. In another study by DawsonHughes and colleagues (19), a threshold concentration of $44 \mathrm{ng} / \mathrm{ml}(110 \mathrm{nmol} / \mathrm{l})$ could be defined on the basis of PTH status in North American elderly. Findings of the SUVIMAX study of middle-aged adults in France suggested a threshold of $31 \mathrm{ng} / \mathrm{ml}(78 \mathrm{nmol} / \mathrm{l})$, on the basis of the relationship between 25-hydroxyvitamin D and PTH serum concentrations (7). In a collaborative study on vitamin D status, Lips and colleagues (20) suggested that serum 25-hydroxyvitamin D values cannot be assumed to be comparable, without a careful cross-calibration between different laboratories for 25hydroxyvitamin $\mathrm{D}$ assays. This might explain a significant part of the variation between the 25hydroxyvitamin D threshold studies stated above, suggesting that understanding of desirable vitamin D 
concentrations in the elderly may need to take between-assay variations into consideration.

In this study, we investigated differences in 25hydroxyvitamin D-iPTH interaction between ambulatory elderly in summertime (expected maximum vitamin $D$ repletion) and institutionalized elderly in wintertime (expected nadir in vitamin D status). The relationship between 25 -hydroxyvitamin $\mathrm{D}(5 \mathrm{ng} / \mathrm{ml}$ increments) and iPTH serum concentrations differed markedly between ambulatory elderly in summertime and institutionalized elderly in wintertime, although their overall median iPTH serum concentrations were similar. In institutionalized elderly, median serum iPTH concentrations were about $30 \mathrm{pg} / \mathrm{ml}$ for 25 -hydroxyvitamin D concentrations between 6 and $30 \mathrm{ng} / \mathrm{ml}$, whereas in ambulatory elderly the median iPTH serum concentrations were greater, between 40 and $50 \mathrm{pg} / \mathrm{ml}$ at low vitamin D concentrations. Institutionalized elderly attained median iPTH serum concentrations greater than $40 \mathrm{pg} / \mathrm{ml}$ only as serum concentrations of 25-hydroxyvitamin D decreased to less than $6 \mathrm{ng} / \mathrm{ml}$. These findings could be explained by the immobility-induced bone loss in the institutionalized elderly, proposed above, which might pre-empt the development of $2^{\circ} \mathrm{HPT}$ by increasing bone resorption and serum calcium. Assay variation could not be an explanation for differences between ambulatory and institutionalized elderly within this study, as the same assay was used by one laboratory for all participants.

Our results show that, although the incidence of vitamin $\mathrm{D}$ deficiency was about six times greater in institutionalized elderly in wintertime, mean iPTH serum concentrations were similar to those of ambulatory elderly in summertime. Bone turnover was associated with low physical mobility, but not with vitamin D deficiency or iPTH concentrations.

The clinical implications of these findings would suggest that interventions aimed at increasing physical mobility may prove useful in augmenting the effect of vitamin D supplementation in frail elderly. In addition, our results suggest that a further refinement of the understanding of desirable vitamin D concentrations in the elderly may need to take levels of activity into consideration.

\section{Acknowledgements}

This study was funded partly by a grant from the Eidgenössische Kommission für Rheumaforschung and Internationale Stiftung zur Förderung der Ernährungsforschung und Aufklärung. No commercial party had a direct financial interest in the results of the research.

\section{References}

1 Boullion RA, Auwerx JH, Lissens WD \& Pelemans WK. Vitamin D status in the elderly: seasonal substrate deficiency causes 1,25 dihydroxycholecalciferol deficiency. American Journal of Clinical Nutrition $198745755-763$.
2 Thompson SP, Wilton TJ, Hosking DJ, White DA \& Pawley E. Is vitamin D necessary for skeletal integrity in the elderly? Journal of Bone and Joint Surgery 1990 72-B 1053-1056.

3 McKenna MJ. Difference in vitamin D status between countries in young adults and the elderly. American Journal of Medicine 1992 $9369-77$.

4 van der Wielen RPJ, Löwik MRH, van der Berg H, CPGM de Groot L, Haller J, Moreiras O et al. Serum vitamin D concentrations among elderly people in Europe. Lancet 1995 346 207-210.

5 Brazier M, Kamel S, Malmer M, Agbomson F, Eleper I, Garabedien $\mathrm{M}$ et al. Markers of bone remodeling in the elderly: effect of vitamin D insufficiency and its correction. Journal of Bone and Mineral Research 199511 1753-1761.

6 McKenna MJ \& Freaney R. Secondary hyperparathyroidism in the elderly: means to defining hypovitaminosis D. Osteoporosis International. 19988 (Suppl) 3-6.

7 Lips P. Vitamin D deficiency and osteoporosis: the roe of vitamin D of osteoporosis-related fractures. European Journal of Clinical Investigation 199626 436-442.

8 Kinyamu H, Gallagher JC, Petranik KM \& Ryschon KL. Effect of parathyroid hormone (hPTH 1-34) infusion on serum 1,25dihydroxyvitamin $\mathrm{D}$ and parathyroid hormone in normal women. Journal of Bone and Mineral Research 199611 1400-1405.

9 Perrig-Chiello P, Perrig WJ, Stähelin HB, Krebs E \& Ehrsam R. Autonomie, Wohlbefinden und Gesundheit im Alter. Zeitschrift für Gerontologie und Geriatrie 199629 95-109.

10 Widmer LK, Stähelin HB, Nissen C \& daSilva A. Venen-ArterienKrankheiten und koronare Herzkrankheiten bei Berufstätigen. Bern: Huber, 1981.

11 Burckardt P. Breakthrough: hypercalcaemia as an incidental finding: what has to be done. Newsletter of Nichols Institute 1994 II 1-5 (Letter).

12 Lips P, Netelenbos JC \& Jongen MJM. Histomorphometric profile and vitamin D status in patients with femoral neck fracture. Metabolism, Bone Disease and Related Research 19824 85-93.

13 Burnand B, Sloutskis D, Gianoli F, Cornuz J, Rickenbach M, Paccaud F et al. Serum 25-hydroxyvitamin D: distribution and determinants in the Swiss population. American Journal of Clinical Nutrition $199256537-542$.

14 Chapuy MC, Schott AM, Garnero P, Hans D, Delmas PD, Meunier PJ \& Epidos study group. Healthy elderly women living at home have secondary hyperparathyroidism and high bone turnover in winter. Journal of Clinical Endocrinology and Metabolism 199681 1129-1133.

15 Stewart AF, Adler M, Byers CM, Segre GV \& Broadus AE. Calcium homeostasis in immobilization: an example of resorptive hypercalciuria. New England Journal of Medicine 1982306 1136-1140.

16 LeBlanc A, Schneider V, Spector E, Evans H, Rowe R, Lane H, Demers L \& Lipton A. Calcium absorption, endogenous excretion, and endocrine changes during and after long-term bed rest. Bone 199516 301-304.

17 Oganov VS, Grigoriev AI, Voronin LI, Rakhmanov AS, Bakulin AV, Schneider V \& LeBlanc A. Bone mineral density in cosmonauts after 4.5-6 month long flights aboard orbital station MIR. Aerospace and Environmental Medicine 199226 20-24.

18 Sorva A, Välimäki M, Ristelli J, Ristelli L, Elfving S, Takkunen H \& Tilvis R. Serum ionized calcium, intact PTH and novel markers of bone turnover in bedridden elderly patients. European Journal of Clinical Investigation 199424 806-812.

19 Dawson-Hughes B, Harris SS \& Dallal GT. Plasma calcidiol, season, parathyroid hormone concentrations in healthy elderly men and women. American Journal of Clinical Nutrition 199765 67-71.

20 Lips P, Chapuy MC, Dawson-Hughes B, Pols HA \& Holick MF. An international comparison of 25-hydroxyvitamin D measurements. Osteoporosis International 19999 394-397.

Received 23 February 2000

Accepted 3 July 2000 